\title{
Effect of Tillage Techniques on Depth, Furrow Slice and Water Retention in Maugo Smallholder Rice Scheme in Kenya
}

\author{
Pius Kipchumba Cheboi ${ }^{1, a}$, Clement Kiprotich Kiptum ${ }^{1, b, *}$, Japheth O. Onyando ${ }^{2, c}$ \\ ${ }^{1}$ School of Engineering, University of Eldoret, P.O. Box 1125 Eldoret, Kenya \\ ${ }^{2}$ School of Engineering, Egerton University, P.O. Box 536 Egerton, Kenya
}

*Corresponding author

A R T I C L E IN F O A B S T R A C T

Research Article

This study was conducted with the aim of determining the influence of tillage techniques on depth, furrow slice and water retention in Maugo Smallholder Rice Scheme in Kenya. Treatments were arranged in randomized complete block design with four replicates. Four tillage treatments were used. The first one was conventional ox plough practiced by farmers where they first flood the field with

Received : $12 / 09 / 2020$

Accepted : 24/12/2020 water before ploughing. The other three treatments were ox plough, hand hoe and tractor ploughing all with no flooding before ploughing. Data collected included depth of ploughing and harrowing during land preparation. Furrow slices during ploughing and harrowing as well as water retention were recorded. Tractor ploughing had the highest mean depth of ploughing of $42.00 \pm 0.81 \mathrm{~cm}$ followed by conventional ox ploughing with $17.75 \pm 0.75 \mathrm{~cm}$, ox ploughing $15.75 \pm 0.62 \mathrm{~cm}$ and hand hoe ploughing had the lowest mean depth $15.50 \pm 0.28 \mathrm{~cm}$. Tractor ploughing had the largest mean furrow

Keywords:

Furrow slice size of $62.00 \pm 0.91 \mathrm{~cm}$ followed by conventional ox ploughing $32.25 \pm 0.85 \mathrm{~cm}$, ox ploughing 30.25

Maugo rice

Tillage

$\pm 0.85 \mathrm{~cm}$ while hand hoe ploughing had the smallest mean furrow slice of $16.5 \pm 0.50 \mathrm{~cm}$. Highest mean of retained water was recorded in week 4 in paddy rice fields prepared using conventional ox

Water retention

Ploughing ploughing $(10.5 \mathrm{~cm})$, ox ploughing $(10 \mathrm{~cm})$, hand hoe ploughing $(11.5 \mathrm{~cm})$ and tractor ploughing $(11.5$ $\mathrm{cm})$ while the lowest was recorded in week 15 for conventional plots. There were significant differences in mean depths during both ploughing and harrowing. Tractor ploughing mean depths were significantly different from the other treatments. The weekly mean water depths retained in the plots were more than $6 \mathrm{~cm}$ for the entire growing period of rice.

\section{a picheboi2014@gmail.com c ionyando@gmail.com

\section{Introduction}

More than half of the earths' inhabitants consume rice (Oriza sativa L.) as their staple food (Prodhan and Qingyao, 2020). At moisture content of 12 percent, rice has 80 percent starch and 7 percent protein (Del Rosario et al.,1968). Total annual world production of rice in 2018 stood at 0.8 billion metric tons (FAO, 2020). Although area under rice farming is increasing in Kenya, its production is stagnating because of the challenges faced by smallholder farmers who contribute $63 \%$ food produced in the country (FAO, 2015).

Smallholder farmers in the study area have an average land size of 4 acres used for both homestead and farming purposes (GoK, 2013). Therefore, solving challenges faced by smallholder farmers will lead to increase in rice productivity consequently solving the problem of food insecurity in Kenya. This will also help reduce rice imports in Kenya which stood at 0.6 million tonnes in 2019 (Knoema, 2019). In fact, one of the "Big-Four" priorities of Kenyan president for the period 2017 to 2022 is achievement of $100 \%$ food and nutrition security (World Food Programme, 2018). Rice production can be improved through proper land preparation and proper irrigation among other agronomic requirements for rice crop.

Tillage method is crucial in cultivation of crops (Sornpoon and Jayasuriya, 2013). This is because knowledge of tillage effect on soil physical properties is essential for plant growth. Irrigation is one of the most effective ways to develop smallholder agriculture and contribute to poverty reduction through increasing crop yield and income (Domenech, 2015). One of the Kenya's irrigation sector is the smallholder community irrigation schemes which are owned, operated and managed by the farmers through their irrigation water users' associations. They are developed on a cost-sharing basis between the government, communities and development partners. An example of smallholder irrigation scheme is Maugo in Homa Bay County in Kenya. 
Land preparation techniques may influence water retention and yields of rice. No tillage is considered the best alternative to ploughing and harrowing due to its effect on soil properties but ploughing, harrowing and levelling increases rice yield and reduces weed density. Information on the effect of different land preparation techniques on water retention and rice yields in the smallholder irrigation schemes like Maugo Irrigation scheme is scanty. Therefore, this study aimed to study the effect of land preparation techniques on ploughing and harrowing depth as well as water retention. The information in this study will assist Kenya to make progress in achievement of Sustainable Development Goal number 2 on Zero hunger (United Nations, 2015).

\section{Materials and Methods}

\section{Study Area}

The study was conducted in Powo B sub-block (Latitude $0^{\circ} 23^{\prime} \mathrm{S}$, Longitude 34 ${ }^{\circ} 30^{\prime}$ 'E and altitude 1020 metres above sea level) which is part of Maugo Irrigation Scheme. The experiments were done from July 2019 to January 2020 season. The study area falls under agroecological zone lower midland (LM3), with mean annual rainfall ranging from $740 \mathrm{~mm}$ to $1,200 \mathrm{~mm}$. The rainfall has a high variability on duration and amount making up two fairly distinct rainy seasons (long rains peaking between April and May and the short rains peaking between November and December). The mean annual maximum temperature is $31^{\circ} \mathrm{C}$, while the mean annual minimum temperature is $18^{\circ} \mathrm{C}$. Relative humidity varies between $60 \%$ and $75 \%$ and potential evapotranspiration rates range from 1,800 to $2,000 \mathrm{~mm}$ per annum (GoK, 2013). Soils in the study area are clayey with more than $40 \%$ clay with a bulk density of $1.15 \mathrm{~g} / \mathrm{cm}^{3}$ and penetration resistance of 2.0 bars (M'Marete, 1991).

\section{Tillage Treatments}

There were four tillage treatments that were replicated four times and arranged in a randomized complete block design (Picture 1). The first tillage treatment (conventional) was ox ploughing using Victory Ox Plough practiced normally by farmers where they first flood their fields to a depth of $20 \mathrm{~cm}$ before ploughing. The second treatment was ox ploughing with Victory Ox Plough and no flooding. The third treatment was hand hoe ploughing. The last treatment was using a 75 horse power tractor Massey Fergusson (MF 375) with a three bottomed disc plough. The last three treatments were ploughed without flooding. Secondary tillage in form of harrowing was done manually by using hand hoe. This resulted in a total of 16 experimental plots each with an area of $90 \mathrm{~m}^{2}$. There was an alley of one meter between plots and two meters between replications.

\section{Data Collected and Analysis}

Data collected included depth during ploughing and harrowing. Size of furrow slice during ploughing and harrowing was measured. The depth of water entering and leaving the plots were measured to determine the weekly water retained in each plot. Water retained was not measured in week 7 because of the problem of heavy rain that resulted in inaccessibility of the experimental site.
Mean depths during ploughing and harrowing were calculated as well as mean sizes of furrow sizes during ploughing and harrowing. One-way Analysis of Variance (ANOVA) at 0.05 level of significance was done using Microsoft Excel ${ }^{\circledR}$ data analysis tool for both depths and furrow slices during ploughing and harrowing. Also, in Microsoft Excel, t-test with two samples assuming unequal variance was used. Spearman's Rank-order correlation between different treatments was done to gauge the relationship between weekly water retention in the paddy rice field.

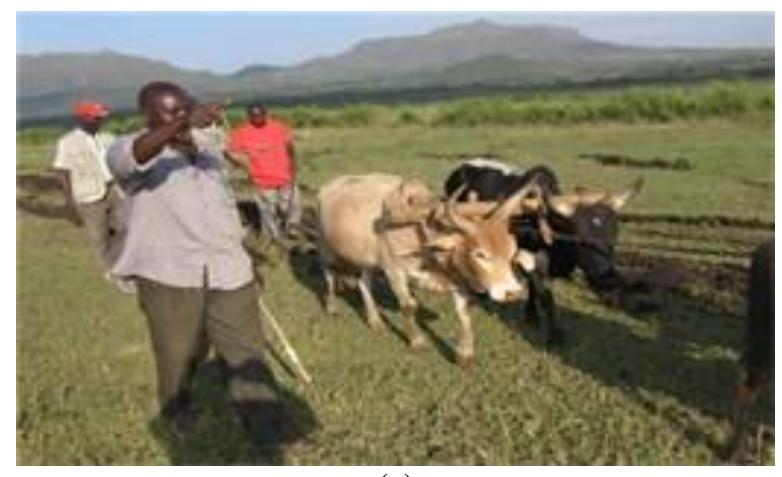

(a)

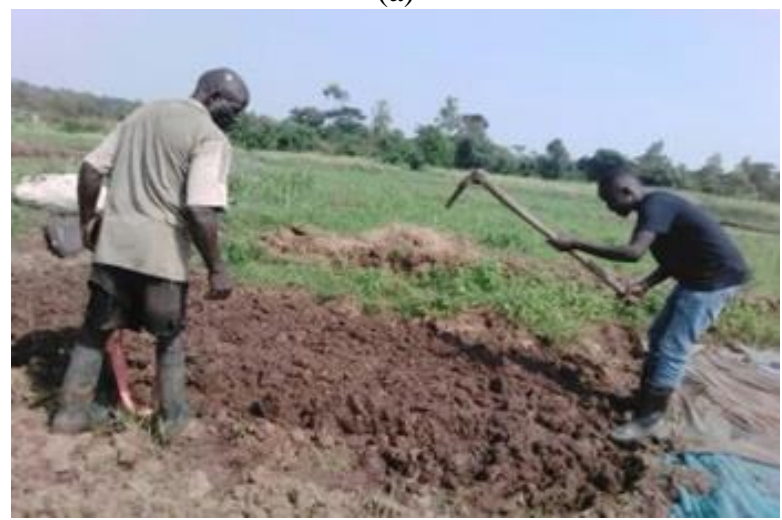

(b)

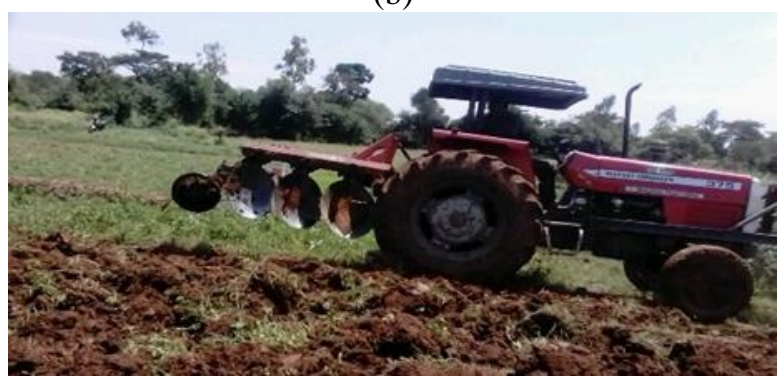

(c)

Picture 1. Ox ploughing (a), hand hoe ploughing (b) and tractor ploughing $(\mathrm{c})$

\section{Results and Discussion}

\section{Depths of Ploughing and Harrowing}

Tractor ploughing had the highest mean depth of ploughing of $42.00 \pm 0.81 \mathrm{~cm}$ followed by conventionalox ploughing with $17.75 \pm 0.75 \mathrm{~cm}$, ox ploughing15.75 \pm $0.62 \mathrm{~cm}$ and hand hoe ploughing had the lowest mean depth $15.50 \pm 0.28 \mathrm{~cm}$. The depth of tractor ploughing was twice the $20 \mathrm{~cm}$ observed by Kareem and Sven, (2015). It was also one and half times the $30 \mathrm{~cm}$ reported by (Tnau Agritech, 2016). Results show that when the ground is wet, the ox plough goes deeper because of wetting of the field. 
During harrowing, hand hoe ploughing had the greatest mean depth of $14.50 \pm 0.05 \mathrm{~cm}$ followed by that of tractor ploughing $13.75 \pm 1.03 \mathrm{~cm}$ while conventional- ox ploughing had mean depth of $11.55 \pm 0.26 \mathrm{~cm}$, and oxploughing had the least mean depth of $11.25 \pm 0.75 \mathrm{~cm}$ as shown in Figure 1. Hand hoe depth was deeper because of its shallower depth of harrowing. Also, hand hoe cannot go deeper than the size of the hoe so larger ploughing depths cannot be reached by use of hoe. There was a significant difference in mean depths during both ploughing and harrowing as shown in Table 1 at $\alpha=0.05$. There was no significant difference between conventional ox plough and the ox plough and also no significant difference between ox plough and hand hoe ploughing. However, there was a significant difference in depth between tractor ploughing and all the other methods during ploughing.

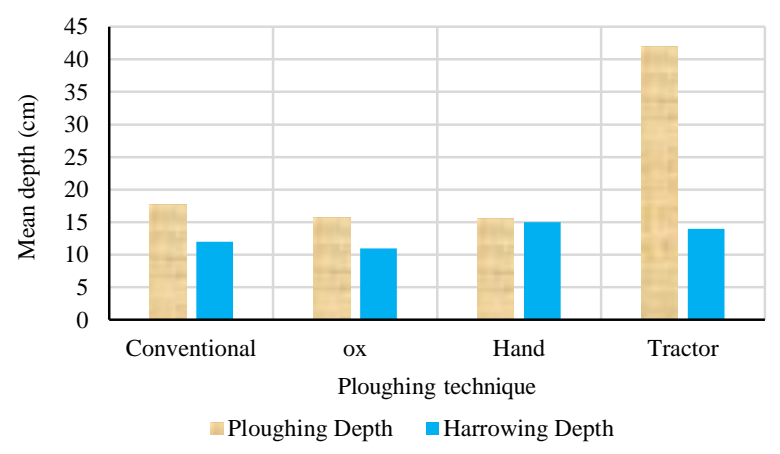

Figure 1. Mean ploughing depths for different ploughing techniques

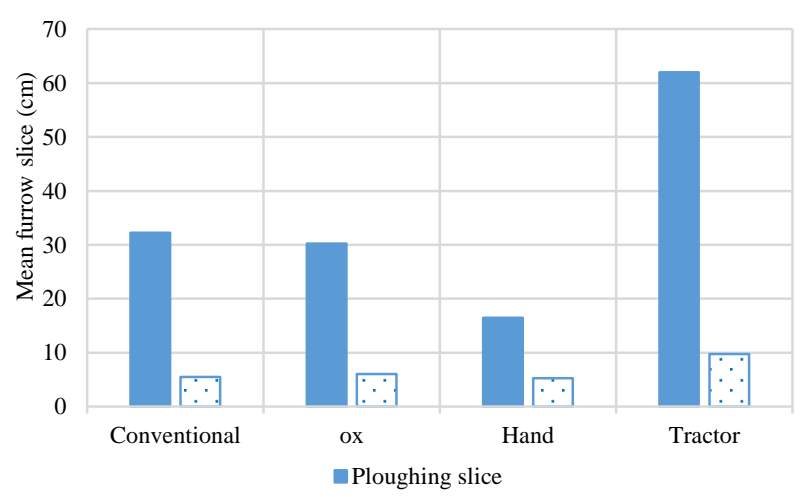

Figure 2. Mean furrow slice for different ploughing techniques

Table 1. Analysis of Variance for depths and furrow slices during ploughing and harrowing

\begin{tabular}{l|ccccc}
\hline & Significance $(\alpha=0.05)$ & Ploughing & \multicolumn{3}{c}{ Harrowing } \\
\cline { 3 - 5 } & & Calculated F & Critical F & Calculated F & Critical F \\
\hline Ploughing depth & Significant $(\mathrm{P}=<0.05)$ & 388 & 3.5 & 5.3 & 3.5 \\
Furrow slice & Significant $(\mathrm{P}=<0.05)$ & 577 & 3.5 & 8.0 & 3.5 \\
\hline
\end{tabular}

\section{Furrow Slice Sizes}

Tractor ploughing had the largest mean furrow size of $62.00 \pm 0.91 \mathrm{~cm}$ followed by conventional- ox ploughing $32.25 \pm 0.85 \mathrm{~cm}$, ox ploughing $30.25 \pm 0.85 \mathrm{~cm}$ while hand hoe ploughing had the smallest mean furrow slice of 16.5 $\pm 0.50 \mathrm{~cm}$. Tractor furrow slice was twice $30 \mathrm{~cm}$ observed by (Tnau Agritech, 2019) The mean size of furrow slice after harrowing was high in tractor ploughing $9.75 \pm 1.03$ $\mathrm{cm}$ followed by that of ox-ploughing $6.00 \pm 0.40 \mathrm{~cm}$ then conventional ox plough $5.50 \pm 0.90 \mathrm{~cm}$ while hand hoe ploughing had the least size of $5.25 \pm 0.48 \mathrm{~cm}$ as portrayed in Figure 2. There was a significant difference in mean furrow slices during both ploughing and harrowing as shown in Table 1 with significant difference observed between tractor ploughing and all the other techniques.

\section{Water Retention}

The water retention during weeks $1,2,3,4,5,10,12$ and 14 in the paddy rice fields for the four ploughing techniques did not differ significantly as represented in Table 2, however, in weeks $6,8,9,11,13$ and 15 they differed significantly. Highest mean water retention was observed in tractor treatment whereas the least was observed in the conventional one using ox plough. It is worth to note that the water retention for tractor ploughing was close to that of hand hoe ploughing. This means that the extra depth during tractor ploughing did not contribute much in water retention. Highest mean of retained water was recorded in week 4 in paddy rice fields prepared using conventional- ox ploughing $(10.5 \mathrm{~cm})$, ox ploughing $(10$ $\mathrm{cm})$, hand hoe ploughing $(11.5 \mathrm{~cm})$ and tractor ploughing
$(11.5 \mathrm{~cm})$ while the lowest was recorded in week 15 . The highest water retention in week 4 was attributed to rainfall received during that week. It is interesting to note that water retention increased in those weeks when rainfall was experienced for example in weeks 3,9 and 11. Water retention decreased whenever there was no rainfall. Therefore, the water retention fluctuated according to rainfall. Higher moisture retention for tractor ploughed field was similar to that observed in Ghana by Bashagaluke et al., (2019) who reported higher soil moisture content in tractor ploughing when compared to other techniques.

Based on Spearman's rank-order correlation; conventional- ox ploughing was positively correlated with ox ploughing $(\mathrm{r}=0.93)$, hand hoe ploughing $(\mathrm{r}=0.91)$ and tractor ploughing $(\mathrm{r}=0.83)$. Looking at the average depths it was found out that the mean depths were more than $6 \mathrm{~cm}$ for the entire growing period with tractor ploughing having higher depths.

\section{Conclusion}

There was enough evidence that tractor ploughing results in deep ploughing depths and big furrow slices during ploughing and harrowing. Highest water retention was observed in both hand hoe and tractor ploughed plots. There was strong correlation between the weekly amount of water between different treatments. The greatest correlation occurred between conventional ox plough (with water) and ox plough (without water). 
Table 2 ANOVA of weekly water retained $(\mathrm{cm})$ in different ploughing techniques

\begin{tabular}{|c|c|c|c|c|c|c|}
\hline & $\begin{array}{l}\text { Conventional- } \\
\text { Ox Ploughing }\end{array}$ & Ox Ploughing & $\begin{array}{l}\text { Hand hoe } \\
\text { Ploughing }\end{array}$ & $\begin{array}{c}\text { Tractor } \\
\text { Ploughing }\end{array}$ & F-Ratio & Critical F \\
\hline Week 1 & $8.50 \pm 0.27$ & $8.25 \pm 0.20$ & $8.83 \pm 0.34$ & $8.38 \pm 0.05$ & 1.06 & 3.49 \\
\hline Week 2 & $6.70 \pm 0.45$ & $6.95 \pm 0.41$ & $7.18 \pm 0.36$ & $8.03 \pm 0.41$ & 1.99 & 3.49 \\
\hline Week 3 & $8.35 \pm 0.21$ & $7.28 \pm 0.26$ & $7.70 \pm 0.20$ & $7.40 \pm 0.76$ & 1.25 & 3.49 \\
\hline Week 4 & $10.50 \pm 0.65$ & $10.00 \pm 0.00$ & $11.50 \pm 0.65$ & $11.50 \pm 0.29$ & 2.45 & 3.49 \\
\hline Week 5 & $9.25 \pm 0.85$ & $10.25 \pm 1.18$ & $9.50 \pm 0.29$ & $11.00 \pm 0.71$ & 0.92 & 3.49 \\
\hline Week 6 & $4.20 \pm 0.51$ & $4.35 \pm 0.49$ & $5.30 \pm 0.27$ & $6.28 \pm 0.47$ & 4.62 & 3.49 \\
\hline Week 8 & $3.68 \pm 0.32$ & $3.73 \pm 0.26$ & $4.75 \pm 0.19$ & $6.23 \pm 0.38$ & 16.27 & 3.49 \\
\hline Week 9 & $7.80 \pm 0.31$ & $8.20 \pm 0.43$ & $7.75 \pm 0.31$ & $3.88 \pm .50$ & 26.26 & 3.49 \\
\hline Week 10 & $5.25 \pm 0.49$ & $5.33 \pm 0.50$ & $6.75 \pm 0.23$ & $5.68 \pm 0.09$ & 3.41 & 3.49 \\
\hline Week 11 & $8.25 \pm 0.37$ & $7.63 \pm 0.11$ & $7.85 \pm 0.28$ & $9.03 \pm 0.31$ & 4.76 & 3.49 \\
\hline Week 12 & $4.65 \pm 0.13$ & $5.35 \pm 1.29$ & $7.88 \pm 0.80$ & $7.13 \pm 0.72$ & 3.18 & 3.49 \\
\hline Week 13 & $3.88 \pm 0.10$ & $3.90 \pm 0.19$ & $5.33 \pm 0.13$ & $7.15 \pm 0.23$ & 84.26 & 3.49 \\
\hline Week 14 & $3.58 \pm 0.28$ & $4.05 \pm 0.15$ & $3.28 \pm 0.10$ & $4.08 \pm 0.43$ & 2.00 & 3.49 \\
\hline Week 15 & $1.60 \pm 0.93$ & $4.15 \pm 0.54$ & $3.85 \pm 0.50$ & $3.75 \pm 0.25$ & 3.75 & 3.49 \\
\hline Average & $6.160 \pm 0.71$ & $6.39 \pm 0.61$ & $6.96 \pm 0.61$ & $7.11 \pm 0.64$ & & \\
\hline
\end{tabular}

\section{References}

Bashagaluke JB, Logah V, Opuku A, Tuffour HO, SarkodieAddo J, Quansah C. 2019. Soil loss and run-off characteristics under different soil amendments and cropping systems in semi-deciduous forest zone of Ghana. Soil Use and Management, DOI://https://doi.org/10.1111/sum.12531

Del Rosario AR, Briones VP, Vidal AJ, and Juliano BO. 1968. Composition and endosperm structure of developing and mature rice kernel. Cereal Chem. 45:225-235.

Domenech L. 2015. Is Reliable Water Access the Solution to Undernutrition? A Review of the Potential of Irrigation to Solve Nutrition and Gender Gaps in Africa South of the Sahara:1-36.

FAO, 2020. Food and Agriculture Organization of the United Nations. FAOSTAT. Available from: http:/www.fao.org/ faostat/en/\#data/QC/visualize[Accessed 28 June 2020]

FAO, 2015. Food and Agriculture Organization of the United States. The economic lives of smallholder farmers. An analysis based on household data from nine countries: 1-48.

GoK, 2013. Government of Kenya. County Government of Homa Bay First County Integrated Development Plan 2013-2017. Nairobi Kenya: 4-6.

Kareem KI, and Sven P.2019. Effect of Ploughing Depth, Tractor forward speed, and plough types on the fuel consumption and tractor performance. Polytechnic Journal, DOI://https://doi.org/ 10.25156/ptj.v9nly2019.pp43-49
Knoema, 2019, Kenya-Rice imports. Available from https://knoema.com/atlas/Kenya/topics/Agriculture/TradeImport-Quantity/Rice-imports-quantity [Accessed 29 June 20201

M'Marete CK. 1991. The bearing capacity of the soils of Ahero irrigated rice fields under exposure to land preparation traffic. MSc Thesis, Department of Agricultural Engineering, University of Nairobi, Nairobi, Kenya.

Prodhan ZH, Qingyao S. 2020. Rice Aroma: A Natural Gift Comes with Price and the WayForward. Science Direct, Rice Science, DOI://https://doi.org/10.1016/j.rsci.2020.01.001

Sornpoon W, Jayasuriya HPW. 2013. Effect of different tillage and residue management practices on growth and yield of corn cultivation in Thailand. Agric Eng Int: CIGR Journal: 86-94

United Nations. 2015. Sustainable Development Goals. Available from https://sustainabledevelopment.un.org/content/documents/ $21252030 \% 20$ Agenda\%20for\%20Sustainable\%20Developm ent\%20web.pdf [Accessed on 11 September 2020]

TNAU AGRITECH/ 2016. Agriculture. Available from http://agritech.tnau.ac.in/agriculture/agri_tillage_tillageimpl ements.html [Accessed on 11 September 2020]

World Food Programme. 2015. Kenya Country Strategic Plan 2018-2023:1-41. 